\title{
Short and Efficient Synthesis of Licochalcone B and D Through Acid-Mediated Claisen-Schmidt Condensation
}

\author{
Zengtao Wang, Zhiguo Liu, ${ }^{\dagger}$ Yongkai Cao, Suresh Paudel, Goo Yoon, ${ }^{\ddagger}$ and Seung Hoon Cheon ${ }^{*}$ \\ College of Pharmacy and Research Institute of Drug Development, Chonnam National University, Gwangju 500-757, Korea \\ EE-mail: shcheon@jnu.ac.kr \\ †School of Pharmacy, Wenzhou Medical College, 1210 University Town, Wenzhou, Zhejiang 325035, China \\ College of Pharmacy and Natural Medicine Research Institute, Mokpo National University, Jeonnam 534-729, Korea \\ Received September 6, 2013, Accepted September 25, 2013
}

Key Words : Licochalcone B, Licochalcone D, Acid-mediated Claisen-Schmidt condensation

Licochalcones A-E and echinatin were isolated and characterized from the roots of licorice (Glycyrrhiza inflata). ${ }^{1-3}$ These retrochalcones are an unusual phenolic compound family and are distinguished from ordinary chalcones by the absence of an oxygen functionality at the C-2' and C-6' positions. ${ }^{1}$ They have various biological activities including anti-cancer, ${ }^{4,5}$ anti-parasitic, ${ }^{6}$ anti-bacterial, ${ }^{7}$ superoxidescavenging ${ }^{7}$ and anti-oxidant activities. ${ }^{8}$ Among the reported retrochalcones, licochalcone $\mathrm{B}$ and $\mathrm{D}$ (Fig. 1) strongly inhibited superoxide anion production in the xanthine/ xanthine oxidase system, and displayed potent scavenging activity on 2,2-diphenyl-1-picrylhydrazyl 1,1-diphenyl-2picrylhydrazyl radicals. ${ }^{7,8}$ Licochalcone $\mathrm{B}$ and $\mathrm{D}$ have also been linked with potent anti-inflammatory activity involving the inhibition of lipopolysaccharide-induced phosphorylation at serine 276 and transcriptional activation of nuclear factor-kappa B. ${ }^{6}$ A recent study reported that licochalcone D inhibits mast cell degranulation by inhibiting extracellular $\mathrm{Ca}^{2+}$ influx and activation of the MEK-ERK pathway. ${ }^{7}$

Chemical synthesis of licochalcone B and D was initiated due to low isolation yield from natural sources and high demand for diverse pharmacological activity studies. ${ }^{2}$ Though the first total synthesis of licochalcone D has been published recently, this synthetic method suffers from limitations including the need for multiple steps, high temperature, and requirement for a special bomb reactor device. ${ }^{9}$ Herein, we report a short, efficient and practical synthesis of licochal-

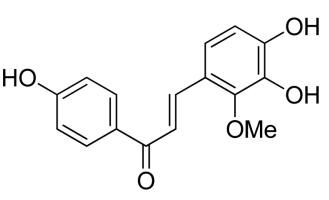

Licochalcone B (1)

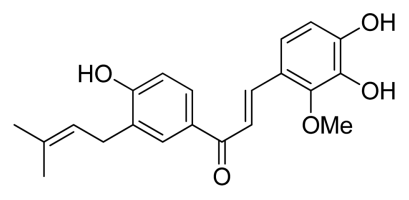

Licochalcone D (2)
Figure 1. Structures of licochalcone B (1) and licochalcone D (2).

cone $\mathrm{B}$ and $\mathrm{D}$ with excellent overall yields.

The synthesis of licochalcone B and D was accomplished by the procedures shown in Scheme 1. As detailed in earlier studies, 3- and 4-hydroxyl groups in 2,3,4-trihydroxybenzaldehyde (3) was selectively protected as methoxymethyl (MOM) ether to give compound 4 in $71 \%$ yield..$^{10}$ Due to the intramolecular hydrogen bond between the 2-hydroxyl group and the neighboring aldehyde group and/or steric hindrance of 2-hydroxyl group, 3-OH and 4-OH in compound 3 are selectively protected. Subsequent methylation on 2-hydroxyl group in $\mathbf{4}$ was carried out using methyl iodide and $\mathrm{NaH}$ in $\mathrm{N}, \mathrm{N}$-dimethylforamide (DMF) to give compound $\mathbf{5}$ in $95 \%$ yield. With the key intermediate $\mathbf{5}$ in hand, we turned our attention to the preparation of $\mathbf{6} \mathbf{b}$ from $\mathbf{6 a}$ to complete the synthesis of licochalcone B and D.

As shown in Scheme 2, attempts to prepare $6 \mathbf{b}$ from $\mathbf{6 a}$ by Friedel-Crafts reaction in the presence of $\mathrm{BaO}-\mathrm{Al}_{2} \mathrm{O}_{3}$ in dichloromethane did not give a satisfactory result (Method<smiles>O=Cc1ccc(O)c(O)c1O</smiles>

3<smiles>COc1ccc(C=O)c(OC)c1OC</smiles>

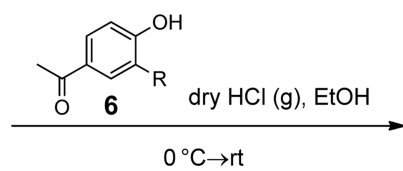

$5(95 \%)$

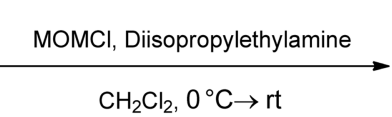<smiles>COc1ccc(C=O)c(OC)c1OC</smiles><smiles>[131In][131In]</smiles><smiles>[R]c1cc(C(=O)/C=C/c2ccc(O)c(O)c2OC)ccc1O</smiles>

Licochalcone D (2, R= $\left.\mathrm{CH}_{2} \mathrm{CHC}\left(\mathrm{CH}_{3}\right)_{2}, 57 \%\right)$

Scheme 1. Synthesis of Licochalcone B and D. 


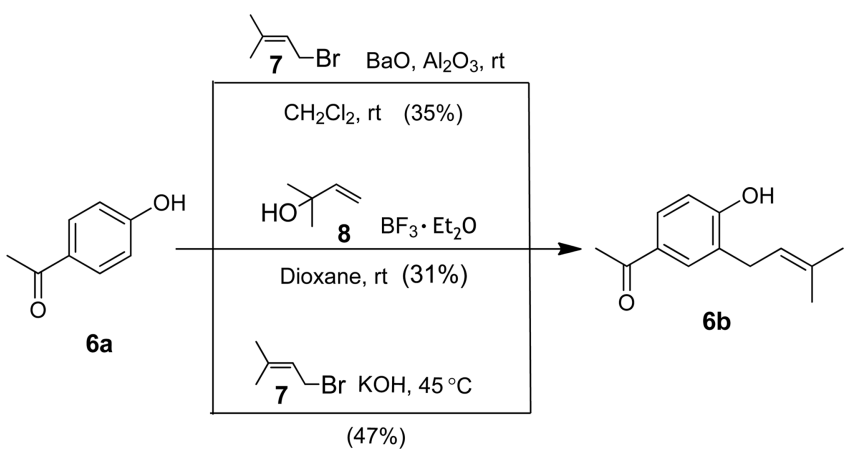

Scheme 2. Synthesis of $\mathbf{6 b}$ from $\mathbf{6 a}$.

A). ${ }^{11}$ This reaction required an extended reaction time of about 4 days to provide the desired product; the best yield was only $35 \%$. Alternatively, treatment of $\mathbf{6 a}$ with 2-methyl3-buten-2-ol and boron trifluoride diethyl ether $\left(\mathrm{BF}_{3} \cdot \mathrm{OEt}_{2}\right)$ as a catalyst in dioxane produced $\mathbf{6 b}$ in $31 \%$ yield based on recovered starting material (Method B). ${ }^{12}$ Recently $C$-prenylation of 4-hydroxybenzaldehyde under strong basic condition has been reported. ${ }^{13}$ Similar treatment of 4-hydroxyacetophenone (6a) with prenyl bromide (7) in aqueous potassium hydroxide (2 eq) solution at $45^{\circ} \mathrm{C}$ gave compound 6b in $47 \%$ yield (Method C). Attempts to reduce $O$-prenylation using common synthetic methods were not successful.

Final condensation reaction between $\mathbf{5}$ and $\mathbf{6}$ to produce licochalcone B and D was examined. Claisen-Schmidt condensation reaction under acidic conditions was chosen to remove the protecting groups and carry out the condensation reaction in one step. This method would have the great advantage of performing aldol condensation and deprotection of the MOM group under acidic conditions at the same time. $^{14}$

Condensation of 2-methoxy-3,4-bis(methoxymethoxy)benzaldehyde (5) with compound $\mathbf{6 a}$ and $\mathbf{6 b}$ in ethanol containing 1.5-2.0 $\mathrm{M}$ of gaseous $\mathrm{HCl}$ provided in high yield the desired licochalcone $\mathrm{B}$ and $\mathrm{D}$, respectively. The spectral data of licochalcone $\mathrm{B}$ and $\mathrm{D}$ were fully consistent with those in the literature. ${ }^{2}$ All the spectral data for licochalcone $\mathrm{B}$ were similar to those of licochalcone $\mathrm{D}$, except for the lack of a prenyl group. The ${ }^{1} \mathrm{H}-\mathrm{NMR}$ spectrum of licochalcone B revealed six characteristic doublets at $\delta 8.00(J=8.7$ $\mathrm{Hz}, 2 \mathrm{H}), \delta 7.84(J=15.9 \mathrm{~Hz}, 1 \mathrm{H}), \delta 7.66(J=15.9 \mathrm{~Hz}, 1 \mathrm{H})$, $\delta 7.33(J=8.7 \mathrm{~Hz}, 1 \mathrm{H}), \delta 6.88(J=8.7 \mathrm{~Hz}, 2 \mathrm{H}), \delta 6.62(J=$ $8.7 \mathrm{~Hz}, 1 \mathrm{H})$, which confirmed the structure of licochalcone $\mathrm{B}$. Only $\mathrm{E}$ isomer as a condensation product with coupling constants of 15.9 and $15.6 \mathrm{~Hz}$ for licochalcone B and licochalcone $\mathrm{D}$, respectively, were isolated.

In summary, a short and efficient synthesis of licochalcone $\mathrm{B}$ and D using 2,3,4-trihydroxybenzaldehyde and 4-hydroxyacetophenone as starting materials in three steps with $42 \%$ and $18 \%$ overall yield, respectively, is described. This is the first reported total synthesis of licochalcone B and a practical preparation of licochalcone $\mathrm{B}$ and $\mathrm{D}$ utilizing an acidmediated Claisen-Schmidt condensation reaction. This result will provide a tool to secure sufficient quantities of licochalcones $\mathrm{B}$ and $\mathrm{D}$ necessary for further biological studies to elucidate the mechanism of action of these compounds. Pharmacological activity studies of these compounds are ongoing, and the results will be reported.

\section{Experimental Section}

General Experiments. All solvents were purchased from OCI (Seoul, Korea). Reagents were obtained from Alfa Aesar or Aldrich and were used without further purification. Silica gel plates (F254; Merck, Germany) and silica gel 60 (70-230 mesh; Merck) were used for analytical and column chromatography, respectively. Melting points were determined in capillary tubes using a capillary melting point apparatus and are not corrected. Nuclear magnetic resonance (NMR) spectra $300 \mathrm{MHz}$ for ${ }^{1} \mathrm{H}-\mathrm{NMR}, 75 \mathrm{MHz}$ for ${ }^{13} \mathrm{C}$-NMR were recorded on a Varian Unity Plus 300 spectrometer, which were performed using $\mathrm{CDCl}_{3}$ or dimethylsulfoxide (DMSO)$d_{6}$ as a solvent at room temperature. Chemical shift $(\delta)$ was expressed in ppm relative to tetramethylsilane used as an internal standard, coupling constant $(J)$ values are estimated in hertz (Hz) and spin multiples are given as s (singlet), $\mathrm{d}$ (doublet), dd (double doublets), m (multiplet), and br (broad). The mass spectra (MS) were acquired in positive mode over 100:600 $\mathrm{m} / \mathrm{z}$ range using a Varian 1200L triple quadrupole mass spectrometer equipped with electrospray ionization (ESI) source. Compounds were visualized by ultraviolet light.

Compound 4. To a suspended solution of 2,3,4-trihydroxybenzaldehyde $(1.2 \mathrm{~g}, 8 \mathrm{mmol})$ in dichloromethane $(10$ $\mathrm{mL})$ was added $N, N$-diisopropylethylamine $(2.8 \mathrm{~mL}, 17$ $\mathrm{mmol}$ ), and stirred for $15 \mathrm{~min}$ at $0{ }^{\circ} \mathrm{C}$. Methoxymethyl chloride $(1.3 \mathrm{~mL}, 17 \mathrm{mmol})$ was then added drop-wise. The mixture was stirred at $0{ }^{\circ} \mathrm{C}$ for $15 \mathrm{~min}$ then at room temperature for $1 \mathrm{~h}$. The reaction mixture was poured into water and extracted with chloroform. The organic layer was concentrated under reduced pressure, and the residue was subjected to silica gel column chromatography (hexane-EtOAc $=10: 1$ ) to afford 2-hydroxy-3,4-bis(methoxymethoxy)benzaldehyde $(1.37 \mathrm{~g}, 71 \%)$ as a white solid. $\mathrm{mp} 55-56^{\circ} \mathrm{C}$. LCEIMS: $m / z=241[\mathrm{M}-\mathrm{H}]^{-} .{ }^{1} \mathrm{H}-\mathrm{NMR}\left(\mathrm{CDCl}_{3}\right) \delta 11.30(1 \mathrm{H}, \mathrm{s})$, $9.75(1 \mathrm{H}, \mathrm{s}), 7.28(1 \mathrm{H}, \mathrm{d}, J=8.7 \mathrm{~Hz}), 6.82(1 \mathrm{H}, \mathrm{d}, J=8.7$ $\mathrm{Hz}), 5.30(2 \mathrm{H}, \mathrm{s}), 5.20(2 \mathrm{H}, \mathrm{s}), 3.64(3 \mathrm{H}, \mathrm{s}), 3.51(3 \mathrm{H}, \mathrm{s})$. ${ }^{13} \mathrm{C}-\mathrm{NMR}\left(\mathrm{CDCl}_{3}\right) \delta 195.05,157.07,156.07,133.23,130.15$, 116.83, 107.05, 97.91, 94.52, 57.19, 56.49.

Compound 5. To a stirred solution of $4(1.37 \mathrm{~g}, 5.7$ mmol) in DMF (14 mL) was added to a suspension of $\mathrm{NaH}$ (344 $\mathrm{mg}, 60 \%$ in oil, $8.6 \mathrm{mmol})$ in DMF $(16 \mathrm{~mL})$ under cooling with ice-water. After being stirred at the same temperature for $30 \mathrm{~min}$, followed by $\mathrm{CH}_{3} \mathrm{I}(0.54 \mathrm{~mL}, 8.6 \mathrm{mmol})$ at room temperature, and the mixture was stirred at same temperature overnight, which was quenched with an aqueous $\mathrm{NH}_{4} \mathrm{Cl}$ solution (saturated), then extracted with ethyl acetate (EtOAc) and the combined organic layer was washed with water and brine, dried over $\mathrm{MgSO}_{4}$, filtered and concentrated under reduced pressure to give a crude oil, which was purified by silica gel chromatography (hexane-EtOAc $=10: 1$ ) to give a colorless oil liquid (1.38 g, 95\%). ${ }^{1} \mathrm{H}-\mathrm{NMR}$ (300 $\left.\mathrm{MHz}, \mathrm{CDCl}_{3}\right) \delta 10.25(1 \mathrm{H}, \mathrm{d}, J=0.6 \mathrm{~Hz}), 7.60(1 \mathrm{H}, \mathrm{d}, J=$ 
$9.0 \mathrm{~Hz}), 7.01(1 \mathrm{H}, \mathrm{dd}, J=9.0,0.9 \mathrm{~Hz}), 5.28(2 \mathrm{H}, \mathrm{s}), 5.17$ $(2 \mathrm{H}, \mathrm{s}), 4.01(3 \mathrm{H}, \mathrm{s}), 3.63(3 \mathrm{H}, \mathrm{s}), 3.52(3 \mathrm{H}, \mathrm{s}) .{ }^{13} \mathrm{C}-\mathrm{NMR}$ $\left(\mathrm{CDCl}_{3}\right) \delta 188.26,157.08,156.49,138.94,124.05,123.93$, $110.79,98.36,94.41,62.29,56.97,56.17$.

\section{Compound 6b.}

Method A: A solution of 4-hydroxyacetophenone (6a) $(5 \mathrm{~g}, 36.8 \mathrm{mmol})$ in dry THF $(50 \mathrm{~mL})$ was added to a slurry of $\mathrm{BaO}(3 \mathrm{eq})$ and $\mathrm{Al}_{2} \mathrm{O}_{3}(3 \mathrm{eq}$, basic or neutral Type $\mathrm{T}$ or $\mathrm{E}$ for thin layer chromatography; Merck) in dry ether-hexane (55 mL, 1:1). After $2 \mathrm{~h}$, the solvent was evaporated and $2 \mathrm{eq}$ of prenyl bromide in $\mathrm{CH}_{2} \mathrm{Cl}_{2}(90 \mathrm{~mL})$ was added. After 4 days the solid was filtered off and washed with $1 \%$ HOAcEtOAc. The combined organic layers were evaporated and compound $\mathbf{6 b}$ was obtained as a white-pale yellow crystalline solid ( $2.63 \mathrm{~g}, 35 \%)$ over silica gel column using mixtures of hexanes and EtOAc (10:1 to 7:1) as eluent.

Method B: Compound 6a (25 g) in $150 \mathrm{~mL}$ dioxane was added to a stirred fresh solution of 2-methyl-3-buten-2-ol $(20 \mathrm{~g})$ and $12.5 \mathrm{~mL} \mathrm{BF}_{3} \cdot \mathrm{OEt}_{2}$ in $100 \mathrm{~mL}$ dioxane, and stirring was continued for $5 \mathrm{~h}$ at room temperature. Ether $(250 \mathrm{~mL})$ was added and the resulting solution was extracted with water $(3 \times 500 \mathrm{~mL})$. The remaining organic layer was dried over $\mathrm{MgSO}_{4}$ before evaporation to dryness. The crystalline residue was extracted with hexane $(5 \times 50 \mathrm{~mL})$, which dissolved the reaction products and left behind most unchanged starting material. After evaporation of the solvent in vacuo the crude residue was purified by flash chromatography (hexane:EtOAc = 10:1) to give $6 \mathbf{b}(4.65 \mathrm{~g}, 31 \%)$ based on recovered compound $\mathbf{6 a}(15 \mathrm{~g}, 60 \%)$.

Method C: 4-Hydroxyacetophenone (6a, $2 \mathrm{~g}, 14.7 \mathrm{mmol})$ was dissolved in aqueous potassium hydroxide $(0.82 \mathrm{~g}$ in 8 $\mathrm{mL}$ water, $14.7 \mathrm{mmol}$ ) solution at room temperature. To this solution, 3,3-dimethylallyl bromide $(3.5 \mathrm{~g}, 23.7 \mathrm{mmol})$ and aqueous potassium hydroxide $(0.82 \mathrm{~g}$ in $8 \mathrm{~mL}$ water, 14.7 $\mathrm{mmol}$ ) were added simultaneously, in portion-wise over $1 \mathrm{~h}$ and the reaction mixture was stirred for $48 \mathrm{~h}$ at around $45^{\circ} \mathrm{C}$. After completion of the reaction (monitored by TLC), the reaction mass was basified further with potassium hydroxide ( $0.82 \mathrm{~g}$ in $8 \mathrm{~mL}$ water, $14.7 \mathrm{mmol})$ and extracted with toluene $(2 \times 10 \mathrm{~mL})$ to remove $O$-prenylated product. The aqueous layer was then acidified with acetic acid at ice water bath temperature to $\mathrm{pH} 5.0$ and was extracted with ethyl acetate $(3 \times 10 \mathrm{~mL})$. The organic layer was dried over anhydrous $\mathrm{MgSO}_{4}$ and evaporated under reduced pressure to obtain the product $(1.82 \mathrm{~g})$. The crude product obtained was column chromatographed on silica gel (hexane-EtOAc $=10: 1$ ) to afford the pure product $(6 \mathbf{b}, 1.41 \mathrm{~g}, 47 \%)$.

Compound 6b: $m p$ 81-83 ${ }^{\circ} \mathrm{C}$. LC-EIMS: $m / z=203$ [M$\mathrm{H}]^{-} .{ }^{1} \mathrm{H}-\mathrm{NMR}\left(\mathrm{CDCl}_{3}\right) \delta 7.79(1 \mathrm{H}, \mathrm{d}, J=2.1 \mathrm{~Hz}), 7.75(1 \mathrm{H}$, dd, $J=8.4,2.1 \mathrm{~Hz}), 7.43(1 \mathrm{H}, \mathrm{s}, \mathrm{br}), 6.91(1 \mathrm{H}, \mathrm{d}, J=8.4$ $\mathrm{Hz}), 5.30-5.36(1 \mathrm{H}, \mathrm{m}), 3.40(2 \mathrm{H}, \mathrm{d}, J=4.2 \mathrm{~Hz}), 2.57(3 \mathrm{H}$, s), $1.76(6 \mathrm{H}, \mathrm{s}) .{ }^{13} \mathrm{C}-\mathrm{NMR}\left(\mathrm{CDCl}_{3}\right) \delta 198.68,159.73,134.17$, $130.76,129.36,128.81,127.86,121.29,115.17,28.80$, 26.18, 25.69, 17.78 .

Licochalcone B and D (1 and 2). Compound 5 (1.0 eq) and intermediate $6 \mathbf{a}$ or $\mathbf{6 b}(1.1 \mathrm{eq})$ were dissolved in anhydrous EtOH, cooled by ice-water bath, then anhydrous 2.0
M HCl-EtOH (6 eq) was added slowly to the stirred solution. The mixture was continuously stirred for $15-20 \mathrm{~h}$ at $0{ }^{\circ} \mathrm{C}$. When the starting martial $\mathbf{6 a}$ or $\mathbf{6 b}$ disappeared (monitored by TLC), then the mixture was kept stirring at room temperature for 8-12 h. $\mathrm{HCl}$ and $\mathrm{EtOH}$ solvent were removed under reduced pressure, and the residue was then extracted with EtOAc, washed with $\mathrm{H}_{2} \mathrm{O}$, saturated aqueous $\mathrm{NaHCO}_{3}$ solution, and $\mathrm{H}_{2} \mathrm{O}$. After the extracted organic layer was dried over $\mathrm{MgSO}_{4}$, and filtered, the solvent was removed under reduced pressure. Licochalcone B (1) or licochalcone D (2) was obtained as a yellow solid after silica gel column chromatography using mixture of chloroformmethanol-acetic acid (200:4:1) as an eluent.

Licochalcone B (1, 62\%): $\mathrm{mp} 196-198^{\circ} \mathrm{C}$. LC-EIMS: $\mathrm{m} / \mathrm{z}$ $=285[\mathrm{M}-\mathrm{H}]^{-} .{ }^{1} \mathrm{H}-\mathrm{NMR}\left(\mathrm{DMSO}-d_{6}\right) \delta 8.00(2 \mathrm{H}, \mathrm{d}, J=8.7$ $\mathrm{Hz}), 7.84(1 \mathrm{H}, \mathrm{d}, J=15.9 \mathrm{~Hz}), 7.66(1 \mathrm{H}, \mathrm{d}, J=15.9 \mathrm{~Hz})$, $7.33(1 \mathrm{H}, \mathrm{d}, J=8.7 \mathrm{~Hz}), 6.88(2 \mathrm{H}, \mathrm{d}, J=8.7 \mathrm{~Hz}), 6.62(1 \mathrm{H}$, d, $J=8.4 \mathrm{~Hz}$ ), $3.77(3 \mathrm{H}, \mathrm{s}) .{ }^{13} \mathrm{C}-\mathrm{NMR}$ (DMSO- $\left.d_{6}\right) \delta 187.27$, $172.53,162.01,149.90,148.63,138.47,138.28,130.92$, $129.56,119.48,119.02,118.53,115.41,111.82,60.79$.

Licochalcone D (2, 57\%): $\mathrm{mp} 112-114^{\circ} \mathrm{C}$. LC-EIMS: $\mathrm{m} / \mathrm{z}$ $=353[\mathrm{M}-\mathrm{H}]^{-} .{ }^{1} \mathrm{H}-\mathrm{NMR}\left(\mathrm{CDCl}_{3}\right) \delta 7.92(1 \mathrm{H}, \mathrm{d}, J=15.6$ Hz), $7.87(1 \mathrm{H}, \mathrm{s}), 7.85(1 \mathrm{H}, \mathrm{d}, J=5.1 \mathrm{~Hz}), 7.54(1 \mathrm{H}, \mathrm{d}, J=$ $15.6 \mathrm{~Hz}), 7.20(1 \mathrm{H}, \mathrm{d}, J=9.0 \mathrm{~Hz}), 6.89(1 \mathrm{H}, \mathrm{d}, J=9.0 \mathrm{~Hz})$, $6.78(1 \mathrm{H}, \mathrm{d}, J=8.7 \mathrm{~Hz}), 5.65(3 \mathrm{H}, \mathrm{br}), 5.32-5.37(1 \mathrm{H}, \mathrm{m}), 3.87$ $(3 \mathrm{H}, \mathrm{s}), 3.44(2 \mathrm{H}, \mathrm{d}, J=7.5 \mathrm{~Hz}), 1.81(3 \mathrm{H}, \mathrm{s}), 1.80(3 \mathrm{H}, \mathrm{s}) .{ }^{13} \mathrm{C}-$ NMR $\left(\mathrm{CDCl}_{3}\right) \delta 189.34,158.91,147.24,146.95,138.73$, $136.60,135.70,131.22,131.09,128.97,127.08,121.04$, $120.74,120.35,115.65,111.88,62.27,29.82,25.82,17.97$.

Acknowledgments. This study was financially supported by Chonnam National University, 2011. We also thank the Korea Basic Science Institute (KBSI), Gwangju branch, for performing the NMR and analytical experiments.

\section{References}

1. Saitoh, T.; Shibata, S. Tetrahedron Lett. 1975, 16, 4461.

2. Kajiyama, K.; Demizu, S.; Hiraga, Y.; Kinoshita, K.; Koyama, K.; Takahashi, K.; Tamura, Y.; Okada, K.; Kinoshita, T. Phytochemistry 1992, 31, 3229

3. Yoon, G.; Jung, Y. D.; Cheon, S. H. Chem. Pharm. Bull. 2005, 53, 694.

4. Park, E. J.; Park, H. R.; Lee, J. S.; Kim, J. W. Planta. Med. 1998, $64,464$.

5. Yoon, G.; Kang, B. Y.; Cheon, S. H. Arch. Pharm. Res. 2007, 30, 313.

6. Furusawa, J.-I.; Funakoshi-Tago, M.; Mashino, T.; Tago, K.; Inoue, H.; Sonoda, Y.; Kasahara, T. Int. Immunopharmacol. 2009, 9, 499.

7. Tanifuji, S.; Aizu-Yokota, E.; Funakoshi-Tago, M.; Sonoda, Y.; Inoue, H.; Kasahara, T. Int. Immunopharmacol. 2010, 10, 769.

8. Li, Y.-J.; Chen, J.; Li, Y.; Li, Q.; Zheng, Y.-F.; Fu, Y.; Li, P. J. Chromatogr. A 2011, 1218, 8181.

9. Kim, S.-J.; Jun, J.-G. Bull. Korean Chem. Soc. 2013, 34, 54

10. Saito, S.; Kawabata, J. Tetrahedron 2005, 61, 8101.

11. Liu, Z.; Lee, W.; Kim, S.-N.; Yoon, G.; Cheon, S. H. Bioorg. Med. Chem. Lett. 2011, 21, 3755.

12. Helesbeux, J.-J.; Duval, O.; Ruilet, D.; Seraphin, D.; Rondeau, D. Tetrahedron 2003, 59, 5091.

13. Rao, G. V.; Swamy, B. N.; Chandregowda, V.; Reddy, G. C. Eur. J. Med. Chem. 2009, 44, 2239.

14. Kromann, H.; Larsen, M.; Boesen, T.; Schønning, K.; Nielsen, S. F. Eur. J. Med. Chem. 2004, 39, 993. 